\title{
The Influences of Formal and Informal Institutions on Taiwanese Family-owned Firms' Entry Mode Choice
}

\author{
Chih-Fang Chiu \\ Department of International Business, National Taiwan University, Taiwan
}

Copyright (C) 2015 by authors, all rights reserved. Authors agree that this article remains permanently open access under the terms of the Creative Commons Attribution License 4.0 International License

\begin{abstract}
This study is designed to shed further light on the foreign direct investment (FDI) decision by the family business, and address the question: Under what situation family-owned firms make the entry mode with high risk commitment. The data source for this study was obtained from Taiwan Economic Journal Database. The database is a comprehensive source for Taiwanese firms' foreign direct investments in 13 countries (Japan, U.S., Indonesia, India, France, Finland, Thailand, Malaysia, Netherlands, Philippines, Vietnam, Germany and Korea). This study included 2451 FDI projects. This study demonstrates that the formal and informal institutions influence a family firm's entry mode decision. In the informal institutions, the familyowned firms choose the joint venture (JV) arrangement. In the formal institutions, the family- owned firms choose the wholly owned entry mode. The results display what situation family-owned firms choose the entry mode.
\end{abstract}

Keywords Family-owned Firms, Institutional Factors, Entry Mode

\section{Introduction}

\subsection{Research Gap}

In emerging markets, the characteristic of business group (BG) have been emphasized [1,2,3,4,5,6]. Granovetter [3] defined business groups as "sets of legally independent firms bound together in persistent formal and/or informal ways.' Especially, business group's concentrated ownership is the widespread scenario in emerging markets $[7,8]$. Business group with concentrated ownership has motivation to appropriate the whole capital that facilitates the $\mathrm{BG}$ ownership as endogenous consideration in the process of strategic decision $[3,9,10]$.

Recently, studies have examined that the family business, the specific type of $\mathrm{BG}$, is risk-averse or risk-willing while the family business makes strategic decisions [11.12]. Among of strategic decisions involve resources risk such as foreign investment, international involvement and diversification. On the one hand, previous research has argued that the family business with risk-averse protect the family wealth, and then the family business avoids high risk decisions [13]. On the other hand, studies have proposed that the family business with risk-willing make high risk decisions for creating family value [14]. Therefore, the paradox is that the family business with both risk-averse and risk-willing makes strategic decisions involving resources commitments of high risk.

Remedying the above the research gap, our study is designed to shed further light on the foreign direct investment (FDI) decision by the family business, and address the question: Under what situation family-owned firms make the entry mode with high risk commitment.

This study aims to extend the research of family business and FDI issue. First, we clarify the family-owned firm takes risk-averse or risk-willing in the FDI decision in emerging markets. Second, we explore how the formal and informal institutions influence the family-owned firm to recognize local investment risk and make the FDI mode choice.

\subsection{The Higher Foreign Investment Involves the Higher Risk}

The FDI as contracting process includes information searching and evaluation to decide one mode in the host county [15]. Besides, the different entry modes are characterized by the level of control and resource requirements[16]. The wholly owned entry mode involves relatively higher investment. In contrast, the joint venture mode involves the less resource, and the firm needs to share resource and risk with the local partner. Moreover, the external risk can be transferred to the partner who is able to absorb uncertainty including local culture and institutional factors $[17,18]$. Therefore, the joint venture mode involves the lower risk than the wholly owned entry mode. 


\subsection{Formal and Informal Institutions Impact the FDI Decision}

The factors of formal institutional hazards include voice and accountability, political stability and absence of violence, government effectiveness, regulatory quality, rule of law and control of corruption $[8,19]$.The formal institutional hazards cause systematic uncertainty. High formal institutional hazards increases the likelihood of exposure to contracting hazards, especially assets may be unlawfully appropriated in countries with weak institutional intervention and with high political and legal risks[20]. Family-owned firms have motivations to minimize contracting hazards to protect assets via family control, by utilizing the wholly owned mode to transfer various family controls $[11,12]$.

The informal institutional distance generates unsystematic uncertainty; flexibility and rich experience are needed to deal with uncertainty. The foreign partners consider these kinds of situations and then contribute knowledge to solve operational difficulties stemming from informal institutional distance[21,22]. Foreign partners' local knowledge easily combines with the family assets. The synergy of assets and local knowledge may motivate the family firm to choose the JV arrangement.

\section{Materials and Methods}

\subsection{Data Sources and Sample}

The primary data source for this study was obtained from the Taiwan Economic Journal (TEJ) Database, which contains financial and corporate information on familycontrolled firms. The database is also a comprehensive source for Taiwanese firms' FDI (foreign direct investments) in 13 countries (Japan, U.S., Indonesia, India, France, Finland, Thailand, Malaysia, Netherlands, Philippines, Vietnam, Germany and Korea) from 1999 to 2007. The FDI data were recorded according to investment date, equity ratio and where the projects are located. This study collected 2451 FDI projects.

\subsection{Variables}

Dependent variables. The dependent variable was the entry mode. Family-controlled firms with $95 \%$ or higher invested in host countries, including acquisition and Greenfield modes were created with a dummy variable of 1 . The family-controlled firms with less than $95 \%$ investment were created with a variable of 0 to represent minority joint venture and majority joint venture modes. Examining wholly-owned and joint venture modes of entry is consistent with past studies Independent variables. Family Ownership was measured by the percentage of shares held by group business. Family control higher than 50\% of stocks in firms represents family-controlled firms. We created a dummy variable of 1 . A dummy variable of 0 was created to represent non-family-controlled firms.
Moderator variables: Kaufmann, Kraay and Mastuzzi have produced Worldwide Governance Indicators (WGI) from 1996. They define that governance consists of the traditions and institutions by which authorities in a country is exercised. We use these indicates to measure formal institution hazards. Foreign firms loss the appropriation of assets while the score of WGI is low. Formal institutions included six dimensions of governance quality: voice and accountability, political stability and absence of violence, government effectiveness, regulatory quality, rule of law and control of corruption. Each item was rated between 0 and $100 \%$. We combined six dimensions into one variable and created 1 for the high quality of formal institutions. A dummy variable of 0 was to represent the low quality of formal institutions. Informal institutional distance referred to four cultural dimensions: power distance, uncertainty avoidance, masculinity/ femininity, and individualism $[23,24]$. The formula is as follows:

$$
C D_{j}=\sqrt{\sum_{i=j}^{4} \frac{\left(I_{i j}-I_{i t}\right)^{2}}{V_{i}}}
$$

Control variables. At firm-level, we controlled for $\mathrm{R}$ and D expenditure, advertising expenditure and the variables of cooperate governance. Prior studies have suggested a positive effect of $\mathrm{R}$ and $\mathrm{D}$ expenditure due to avoidance of opportunism by local partners [24]. Similar to advertising expenditure, the free-riding problem should be reduced through higher equity mode [24]. We control for the mechanisms of governance that may also affect the choice of mode (i.e., the ratio of independent directors, the ratio of Managers=directors, and directors equity \%) [25]. Industries were also controlled: electronics, transportation, plastics, automobiles, etc (omitted category).

\section{Results}

Table 1 shows the descriptive statistics and correlation matrix to variables. The regression result for the multinomial logistic model is shown in Table 2.

Model 1 in Table 2 only contains the control variables. Model 2 tests the entry mode choice of family-owned firms with formal institutions. The Model $\chi^{2}$ value of Model 2 is $2725.968(p<0.001)$, indicating high explanatory power of the model. Coefficient of the term of interaction of family firm and formal institutions is positively significant $(\beta=$ $0.493, \mathrm{p}<0.05$ ). The result confirms that family-owned firms with formal institutions are more likely than non-family firms to choose wholly owned mode. Model 2 also tests the entry mode choice of family-owned firms with informal institutions. The Model $\chi^{2}$ value of Model 2 is $169.233(\mathrm{p}<$ 0.001 ), indicating high explanatory power of the model. Coefficient of the term of interaction of family firm and informal institutions is negatively significant $(\beta=-0.684, p<$ $0.05)$. The result confirms that family-owned firms with informal institutional distance are more likely than 
non-family firms to choose joint venture mode.

\section{Discussion and Conclusions}

The aim of our study was to introduce the family-owned firms' entry mode choice in different institutional contexts. The most striking finding of the study is that family-owned firms choose JV in regard to informal institutions, but choose wholly owned mode in regard to formal institutions. The results indicate that family-owned firms adopt high risks in the high quality of formal institutions. Regarding informal institutional distance, the family-owned firms choose the JV arrangement. Our results indicate that the family-owned and -controlled businesses utilize the risk-avoiding attitude in the informal institutional context.

In conclusion, our study may provide some evidence that address theoretical implications behind the motivations of governance on family firms' FDI decisions. An in-depth understanding of the environment context needs to be considered in countries with various institutions. According to our findings above, this study extends the existing literature on FDI. Traditionally, based on the transactional cost perspective, the institutional factors as country-level risk influence inconsistent FDI decisions $[15,16]$. In line with previous findings, the informal and formal institutional factors have different influences through the attitude of family-owned firms to significantly impact their entry mode choice. Therefore, the institutional factors might be cooperative opportunities instead of the country-level risk.

Our findings also suggest that future research should not focus on the direct links between the characteristics of family-owned firms and decision making. The findings show that the family firm's decision depends on various attitudes and situations beyond the existing literature [26]. The firm-level characteristics and country-level context are reconciled when the family firm adopts the appropriate decision. Family firms must be taking into consideration a wide range of institutional factors to avoid making decisions in a vacuum state. Family firms can leverage the characteristics of stewardship and agent to overcome the institutional challenges, especially in Asia with family characteristics of enterprises to enter the overseas market, and how characterized by the use of family decision-making. If firms do not considerate overseas institutional environment, firms would likely miscalculate overseas risks and benefits. Our research shows that family firms face pressure to the formal institutional situation, and adopt economical thoughts to manage the obvious institutional environment. However, if the family firms face informal cultural factors to adopt social cooperative governance model would help to overcome the cultural factors. Therefore, choosing an appropriate mode of governance would avoid losses caused by wrong decisions.

This study has some limitations. First, our FDI data is collected from secondary data that might be underestimated the rich content of family firms such as social capital and human capital. Second, this study may be not able to capture comprehensive institutional factors. It is possible that future research may examine the circumstances regarding the other institutional factors to address the limitation of our study, using the cultural distance index and formal institutional distance. Future research can propose such a possibility to include the elaborate thought of cultural content such as Luo and Shenkar [27]. Comparing different phenomena (various institutions) facilitates understanding the nature of family firms in foreign environment. 
Table 1. Descriptive statistics and Pearson correlations

\begin{tabular}{|c|c|c|c|c|c|c|c|c|c|c|c|c|c|c|c|c|c|c|c|c|c|c|c|}
\hline & & Mean & S.D & 1 & & 2 & & 3 & & 4 & & 5 & & 6 & & 7 & & 8 & & 9 & & 10 & \\
\hline 1 & Entry mode & 0.71 & 0.46 & 1 & & & & & & & & & & & & & & & & & & & \\
\hline 2 & Family firm & 0.86 & 0.34 & -0.01 & & 1 & & & & & & & & & & & & & & & & & \\
\hline 3 & $\begin{array}{c}\text { Formal institutional } \\
\text { hazards }\end{array}$ & 0.67 & 0.47 & 0.19 & $* * *$ & -0.02 & & 1 & & & & & & & & & & & & & & & \\
\hline 4 & $\begin{array}{c}\text { Informal institutional } \\
\text { distance }\end{array}$ & 2.06 & 0.82 & 0.19 & $* * *$ & -0.03 & & 0.76 & $* * *$ & 1 & & & & & & & & & & & & & \\
\hline 5 & $\begin{array}{l}\text { Foreign investing } \\
\text { experience }\end{array}$ & 2.67 & 2.81 & 0.03 & & 0.04 & $* *$ & -0.12 & $* * *$ & -0.15 & $* * *$ & 1 & & & & & & & & & & & \\
\hline 6 & Local investing experience & 1.26 & 2.23 & 0.04 & $*$ & 0.07 & $* * *$ & 0.09 & $* * *$ & 0.14 & $* * *$ & 0.61 & $* * *$ & 1 & & & & & & & & & \\
\hline 7 & Firm size & 6.54 & 1.33 & 0.00 & & 0.25 & $* * *$ & -0.07 & $* * *$ & -0.07 & $* * *$ & 0.22 & $* * *$ & 0.19 & $* * *$ & 1 & & & & & & & \\
\hline 8 & RandD intensity & 3.29 & 9.34 & 0.01 & & -0.02 & & 0.09 & $* * *$ & 0.09 & $* * *$ & -0.06 & $* *$ & -0.04 & $*$ & -0.13 & $* * *$ & 1 & & & & & \\
\hline 9 & Advertisement intensity & 0.01 & 0.01 & -0.02 & & 0.06 & $* *$ & -0.03 & & -0.03 & & -0.07 & $* * *$ & -0.02 & & -0.01 & & 0.10 & $* * *$ & 1 & & & \\
\hline 10 & Export \% & 61.27 & 34.64 & 0.14 & $* * *$ & -0.04 & $*$ & 0.20 & $* * *$ & 0.13 & $* * *$ & 0.12 & $* * *$ & 0.13 & $* * *$ & 0.04 & $*$ & -0.01 & & -0.18 & $* * *$ & 1 & \\
\hline 11 & Independent directors \% & 0.06 & 0.12 & 0.02 & & -0.22 & $* * *$ & 0.04 & $* *$ & -0.01 & & 0.26 & $* * *$ & 0.10 & $* * *$ & -0.13 & $* * *$ & 0.04 & $* *$ & -0.06 & $* *$ & 0.12 & $* * *$ \\
\hline 12 & Managers $=$ directors $\%$ & 0.17 & 0.18 & 0.04 & $*$ & 0.20 & $* * *$ & 0.08 & $* * *$ & 0.05 & $* *$ & -0.04 & $* *$ & -0.01 & & 0.07 & $* * *$ & 0.06 & $* *$ & 0.02 & & 0.10 & $* * *$ \\
\hline 13 & Directors equity $\%$ & 23.43 & 14.63 & 0.02 & & 0.01 & & 0.05 & $* *$ & 0.07 & $* * *$ & -0.34 & $* * *$ & -0.25 & $* * *$ & -0.17 & $* * *$ & -0.01 & & -0.02 & & -0.04 & $* *$ \\
\hline 14 & CEO equity $\%$ & 2.15 & 3.37 & 0.09 & $* * *$ & -0.01 & & 0.10 & $* * *$ & 0.06 & $* *$ & -0.11 & $* * *$ & -0.09 & $* * *$ & -0.21 & $* * *$ & 0.06 & $* *$ & -0.02 & & 0.14 & $* * *$ \\
\hline 15 & Board $=\mathrm{CEO}$ & 34.13 & 21.31 & 0.10 & $* * *$ & 0.26 & $* * *$ & 0.10 & $* * *$ & 0.08 & $* * *$ & -0.07 & $* * *$ & -0.03 & & 0.05 & $* *$ & 0.02 & & 0.00 & & 0.19 & $* * *$ \\
\hline 16 & Electronics industry & 0.67 & 0.47 & 0.19 & $* * *$ & 0.05 & $* * *$ & 0.24 & $* * *$ & 0.18 & $* * *$ & -0.01 & & 0.04 & $*$ & -0.02 & & 0.12 & $* * *$ & -0.11 & $* * *$ & 0.39 & $* * *$ \\
\hline 17 & Plastics industry & 0.03 & 0.18 & -0.06 & $* *$ & -0.01 & & -0.08 & $* * *$ & -0.03 & * & 0.03 & & -0.01 & & 0.13 & $* * *$ & -0.06 & $* *$ & -0.06 & $* *$ & -0.09 & $* * *$ \\
\hline 18 & Automobile industry & 0.01 & 0.09 & -0.01 & & 0.03 & & -0.08 & $* * *$ & -0.06 & $* *$ & 0.03 & & 0.00 & & 0.08 & $* * *$ & 0.00 & & 0.02 & & -0.14 & $* * *$ \\
\hline 19 & Transportation industry & 0.03 & 0.18 & -0.05 & $* *$ & -0.05 & $* *$ & -0.03 & & -0.03 & * & 0.03 & * & 0.01 & & 0.01 & & -0.07 & $* * *$ & -0.06 & $* *$ & -0.22 & $* * *$ \\
\hline
\end{tabular}

${ }^{* * * *} p<0.001,{ }^{* * *} p<0.01,{ }^{* *} p<0.05,{ }^{*} p<0.1$ 
Table 1. Descriptive statistics and Pearson correlations (continued)

\begin{tabular}{|c|c|c|c|c|c|c|c|c|c|c|c|c|c|c|c|c|c|c|}
\hline & & 10 & & 11 & & 12 & & 13 & & 14 & & 15 & & 16 & & 17 & 18 & 19 \\
\hline 1 & Entry mode & & & & & & & & & & & & & & & & & \\
\hline 2 & Family firm & & & & & & & & & & & & & & & & & \\
\hline 3 & $\begin{array}{c}\text { Formal institutional } \\
\text { hazards }\end{array}$ & & & & & & & & & & & & & & & & & \\
\hline 4 & $\begin{array}{l}\text { Informal institutional } \\
\text { distance }\end{array}$ & & & & & & & & & & & & & & & & & \\
\hline 5 & $\begin{array}{c}\text { Foreign investing } \\
\text { experience }\end{array}$ & & & & & & & & & & & & & & & & & \\
\hline 6 & $\begin{array}{c}\text { Local investing } \\
\text { experience }\end{array}$ & & & & & & & & & & & & & & & & & \\
\hline 7 & Firm size & & & & & & & & & & & & & & & & & \\
\hline 8 & RandD intensity & & & & & & & & & & & & & & & & & \\
\hline 9 & $\begin{array}{l}\text { Advertisement } \\
\text { intensity }\end{array}$ & & & & & & & & & & & & & & & & & \\
\hline 10 & Export \% & 1 & & & & & & & & & & & & & & & & \\
\hline 11 & $\begin{array}{l}\text { Independent } \\
\text { directors } \%\end{array}$ & 0.12 & $* * *$ & 1 & & & & & & & & & & & & & & \\
\hline 12 & Managers $=$ directors $\%$ & 0.10 & $* *$ & -0.10 & $* * *$ & 1 & & & & & & & & & & & & \\
\hline 13 & Directors equity $\%$ & -0.04 & $* *$ & 0.04 & $*$ & -0.05 & $* *$ & 1 & & & & & & & & & & \\
\hline 14 & CEO equity $\%$ & 0.14 & $* *$ & 0.04 & $* *$ & 0.46 & $* * *$ & 0.08 & $* * *$ & 1 & & & & & & & & \\
\hline 15 & Board $=\mathrm{CEO}$ & 0.19 & $* * *$ & -0.13 & $* * *$ & 0.38 & $* * *$ & 0.01 & & 0.26 & $* * *$ & 1 & & & & & & \\
\hline 16 & Electronics industry & 0.39 & $* * *$ & 0.14 & $* * *$ & 0.19 & $* * *$ & 0.00 & & 0.21 & $* * *$ & 0.21 & $* * *$ & 1 & & & & \\
\hline 17 & Plastics industry & -0.09 & $* * *$ & -0.06 & $* *$ & 0.07 & $* * *$ & -0.07 & $* * *$ & -0.11 & $* * *$ & -0.03 & & -0.26 & $* * *$ & 1 & & \\
\hline 18 & Automobile industry & -0.14 & $* * *$ & -0.04 & $* *$ & -0.04 & $* *$ & 0.04 & $* *$ & -0.05 & $* *$ & -0.06 & $* *$ & -0.12 & $* * *$ & -0.02 & 1 & \\
\hline 19 & $\begin{array}{c}\text { Transportation } \\
\text { industry }\end{array}$ & -0.22 & $* * *$ & -0.08 & $* * *$ & -0.09 & $* * *$ & 0.08 & $* * *$ & -0.11 & $* * *$ & -0.16 & $* * *$ & -0.26 & $* * *$ & -0.03 & $* \quad-0.02$ & 1 \\
\hline
\end{tabular}

${ }^{* * * *} p<0.001,{ }^{* * *} p<0.01,{ }^{* *} p<0.05,{ }^{*} p<0.1$ 
Table 2. The influence of formal international hazards and informal institutional distance on entry mode choice

\begin{tabular}{|c|c|c|c|c|c|c|}
\hline & \multicolumn{3}{|c|}{ Model1 } & \multicolumn{3}{|c|}{ Model2 } \\
\hline & coefficient & S.D. & $p$ & coefficient & S.D. & $p$ \\
\hline Intercept & 0.342 & 0.894 & & -1.561 & 1.043 & \\
\hline Family firm * Formal institutional hazards & & & & 0.493 & 0.251 & $*$ \\
\hline Family firm * Informal institutional distance & & & & -0.684 & 0.278 & $* *$ \\
\hline Family firm & & & & 1.036 & 0.523 & $*$ \\
\hline Formal institutional hazards & & & & -0.271 & 0.238 & \\
\hline Informal institutional distance & & & & 0.909 & 0.264 & $* * *$ \\
\hline Foreign investing experience & 0.003 & 0.037 & & 0.050 & 0.038 & \\
\hline Local investing experience & 0.022 & 0.027 & & -0.034 & 0.029 & \\
\hline Firm size & 0.018 & 0.039 & & 0.041 & 0.041 & \\
\hline RandD intensity & -0.003 & 0.005 & & -0.006 & 0.006 & \\
\hline Advertisement intensity & 2.031 & 3.290 & & 2.782 & 3.411 & \\
\hline Export \% & 0.004 & 0.002 & $* *$ & 0.003 & 0.002 & \\
\hline Independent directors \% & -0.386 & 0.478 & & -0.590 & 0.492 & \\
\hline Managers $=$ directors $\%$ & -0.723 & 0.336 & $*$ & -0.710 & 0.343 & $*$ \\
\hline Directors equity \% & 0.004 & 0.003 & & 0.003 & 0.004 & \\
\hline CEO equity $\%$ & 0.044 & 0.019 & & 0.044 & 0.019 & $*$ \\
\hline Board $=\mathrm{CEO}$ & 0.007 & 0.003 & $* *$ & 0.007 & 0.003 & $* *$ \\
\hline Electronics industry & 0.341 & 0.057 & & 0.289 & 0.059 & \\
\hline Plastics industry & 0.000 & 0.127 & & -0.071 & 0.129 & \\
\hline Automobile industry & 0.238 & 0.263 & & 0.295 & 0.264 & \\
\hline Transportation industry & 0.059 & 0.127 & & -0.022 & 0.130 & \\
\hline 1999 & -0.154 & 0.161 & & -0.167 & 0.164 & \\
\hline 2000 & -0.057 & 0.156 & & -0.084 & 0.159 & \\
\hline 2001 & -0.212 & 0.155 & & -0.265 & 0.159 & \\
\hline 2002 & 0.202 & 0.156 & & 0.174 & 0.159 & \\
\hline 2003 & 0.035 & 0.139 & & 0.040 & 0.143 & \\
\hline 2004 & 0.129 & 0.143 & & 0.098 & 0.146 & \\
\hline 2005 & -0.343 & 0.115 & $* * *$ & -0.353 & 0.117 & $* *$ \\
\hline 2006 & -0.022 & 0.129 & & -0.034 & 0.131 & \\
\hline 2007 & 0.208 & 0.127 & & 0.182 & 0.129 & \\
\hline 2Log Likehood & \multicolumn{3}{|c|}{2734.597} & \multicolumn{3}{|c|}{2725.968} \\
\hline Rseudo- $\mathrm{R}^{2}$ & \multicolumn{3}{|c|}{0.068} & \multicolumn{3}{|c|}{0.094} \\
\hline $\operatorname{LR} \chi^{2}$ & \multicolumn{3}{|c|}{$169.233^{* * *}$} & \multicolumn{3}{|c|}{$237.862 * * *$} \\
\hline Observations & \multicolumn{3}{|c|}{2451} & \multicolumn{3}{|c|}{2451} \\
\hline
\end{tabular}

${ }^{* * *} p<0.001,{ }^{* *} p<0.01,{ }^{*} p<0.05$

\section{REFERENCES}

[1] Chang, S. and J. Hong (2000) "Economic performance of group-affiliated companies in Korea: Intragroup re- source sharing and internal business transaction" Academy of Management Journal 43, 429-448.

[2] Eddleston, K.A., F.W. Kellermanns and R. Sarathy (2008) "Resource configuration in family firms: Linking resources, strategic planning and technological opportunities to performance" Journal of Management Studies 45(1), 26-50.

[3] Granovetter, M. 1995. Coase Revisited: Business Groups in the Modern Economy. Industrial and Corporate Change, 4(1): 93-130.

[4] Khanna, T. and K. Palepu (2000) "Is group affiliation profitable in emerging markets? An analysis of diversified Indian business groups" The Journal of Finance 55(2), 867-891.

[5] Miller, D., J. Lee, S. Chang and I. Le Breton-Miller (2009) "Filling the institutional void: The social behavior and performance of family vs non-family technology firms in emerging markets" Journal of International Business Studies, 
$40(5), 802-817$.

[6] Schulze, W. S., M. H. Lubatkin, R. N. Dino and A. K. Buchholtz (2001) "Agency relationships in family firms: Theory and evidence" Organization Science 12, 99-116.

[7] Claessens, S., S. Djankov and L. Lang (2000) "The Separation of Ownership and Control in East Asian Corporations" Journal of Financial Economics 58(1), 81-112.

[8] La Porta R, F. Lopez-de-Silanes, A. Shleifer and R. Vishny (1999) "Corporate ownership around the world" The Journal of Finance 54, 471-517.

[9] Filatotchev, I., R. Strange, J. Piesse and Y.-C. Lien (2007) "FDI by firms from newly industrialised economies in emerging markets: corporate governance, entry mode and location" Journal of International Business Studies 38(4), 556-572.

[10] Guillen, M. F. (2003) "Experience, Imitation, and the sequence of foreign entry: Wholly owned and joint-venture manufacturing by South Korean firms and business groups in China, 1987-1995" Journal of International Business Studies 34(2), 185-198.

[11] Gomez-Mejia, L. R., K. Haynes, M. Nunez-Nickel, K. Jacobson and J.Moyano-Fuentes (2007) "Socioemotional wealth and business risks in family controlled firms: evidence from Spanish olive oil mills" Administrative Science Quarterly 52, 106-37.

[12] Gomez-Mejia L., M. Makri and M. Kintana (2010) "Diversification decisions in family-controlled firms" Journal of Management Studies 47(2), 223-252.

[13] Ferna'ndez, Z. and M. J. Nieto (2005) "Internationalization strategy of small and medium-sized family businesses: Some influential factors" Family Business Review 18(1), 77-89.

[14] Peng, M. W. and Y. Jiang (2010) "Institutions behind family ownership and control in large firms" Journal of Management Studies 47(2), 253-273.

[15] Hennart, J. F. (2000) The Transaction Cost Theory of the Multinational Enterprise, in C. Pitelis and R. Sugden (Eds.), The nature of the transnational firm (2nd ed.), London: Routledg, 81-116.

[16] Kim, C. W. and P. Hwang (1992) "Global strategy and multinationals' entry mode choice" Journal of International Business Studies 23(1), 29-53.

[17] Hennart, J. R. and S. Reddy (1997) "The choice between mergers/acquisitions and joint ventures: The case of Japanese investors in the United States" Strategic Management Journal $18(1), 1-12$.

[18] Makino, S. and K. E. Neupert (2000) "National culture, transaction costs, and the choice between joint venture and wholly owned subsidiary" Journal of International Business Studies 31(4), 705-713.

[19] Roy, J. P. and C. Oliver (2009) "International joint venture partner selection: The role of the host-country legal environment" Journal of International Business Studies 40(5), 779-801.

[20] Delios, A. and W. J. Henisz (2003) "Political hazards, experience, and sequential entry strategies: The international expansion of Japanese firms, 1980-1998" Strategic Management Journal 24(11), 1153-1164.

[21] Erramilli, M. K. and C. P. Rao (1993) "Service firms' international entry-mode choice: A modified transaction-cost analysis approach" Journal of Marketing 57(3), 19-38.

[22] Brouthers, K. D. and L. E. Brouthers (2001) "Explaining the national cultural distance paradox" Journal of International Business Studies 32(1): 177-189.

[23] Hofstede, G. (1980) Culture's consequences: International differences in work related Values, Beverly Hills, CA: Sage.

[24] Kogut, B. and H. Singh, (1988) "The effect of national culture on the choice of entry mode" Journal of International Business Studies 19(3), 411-432.

[25] Gatignon, H. and E. Anderson (1988) "The multinational corporation's degree of control over foreign subsidiaries: A empirical test of a transaction cost explanation" Journal of Law, Economics, and Organization 4(2), 305-336.

[26] Lien, Y. C., J. Piesse, R. Strange and I. Filatotchev (2005) "The role of corporate governance in FDI decisions: Evidence from Taiwan", International Business Review 14, 739-763.

[27] Luo, Y. and O. Shenkar (2011) "Toward a perspective of cultural friction in international business", Journal of International Management 17 (1), 1-14. 